\title{
Sensory and chemical quality of sapota milk shake
}

\author{
P.J. UBALE, A.S. HEMBADE AND D.M. CHOUDHARI
}

\begin{abstract}
The three levels of pulp of sapota, at 7,8 and 9 per cent were used with three levels of jaggery i.e. 7,8 and 9 per cent to study the sensory and chemical quality of sapota milk shakes. On the basis of sensory evaluation of sapota milk shake prepared with 7 per cent jaggery and 8 per cent pulp was accepted by the all judges therefore this treatment got highest scored than other treatments. The chemical composition of this treatment was observed i.e. protein $(2.43 \%)$, fat $(3.52 \%)$, non-reducing sugar $(5.13 \%)$, reducing sugar $(4.41 \%)$, iron $(1.17 \mathrm{mg} / 100 \mathrm{~g})$, ash $(0.53 \%)$, total solid $(15.20 \%)$ and acidity $(0.16 \%)$.
\end{abstract}

KEY WORDS : Milk, Sapota, Jaggary

How to CITE THIS PAPER : Ubale, P.J., Hembade, A.S. and Choudhari, D.M. (2014). Sensory and chemical quality of sapota milk shake. Res. J. Animal Hus. \& Dairy Sci., 5(2) : 116-121.

Address for correspondence :

P.J. Ubale, Sangamner Taluka Dudhutpadak Sangh Ltd., Rajhans Dairy, Sangamner, AHMEDNAGAR (M.S.) INDIA

Email : balrajdairy_2007@rediffmail.com

Associated Authors':

A.S. Hembade, Department of Dairy Science, Yeshwant Mahavidyalaya, NANDED (M.S.) INDIA

D.M. Choudhari, Section of Animal Science and Dairy Science, Shramshakti College of Agriculture, Sangamner, AHMEDNAGAR (M.S.) INDIA 